\title{
ASSESSING AGRICULTURAL VULNERABILITY IN INDIA USING NDVI DATA PRODUCTS
}

\author{
R. Kaushalya ${ }^{\text {a }}$, V. Praveen Kumar ${ }^{\text {a }}$, S. Shubhasmita ${ }^{\text {a }}$ \\ ${ }^{a}$ Central Research Institute for Dryland Agriculture (ICAR), Santoshnagar, \\ Hyderabad - 500059, India \\ (*kausalya@crida.in; vaddikv@gmail.com; shubhasmita.sahani@gmail.com)
}

Commission VIII, WG VIII/1

KEY WORDS: Agriculture, Climate, Vegetation, Impact Analysis, Multisensor, Multiresolution, Multitemporal, National

\begin{abstract}
:
Impact of climate change on Indian rainfed agriculture was assessed using temporal NDVI data products from AVHRR and MODIS. Agricultural vulnerability was analysed using CV of Max NDVI from NOAA-AVHRR (15-day, 8km) and MODIS-TERRA (16-day, 250m) NDVI data products from 1982 - 2012. AVHRR dataset was found suitable for estimating regional vulnerability at state and agro-eco-sub-region (AESR) level while MODIS dataset was suitable for drawing district-level strategy for adaptation and mitigation. Methodology was developed to analyse NDVI variations with spatial pattern of rainfall using $1^{0} \mathrm{X} 1^{0}$ girded data and spatially interpolating it to estimate Standard Precipitation Index. Study indicated large variations in vegetation dynamics across India owing to bio-climate and natural resource base. IPCC framework of vulnerability and exposure was used to identify vulnerable region extending from arid western India to semi-arid and dry sub-humid regions in central India and southern peninsula. This is a major agricultural region in the country with sizable human and livestock population with millions of marginal and small farm holdings. Exposure to climatic variability at local and regional levels have national implications and study indicated that over 122 districts extending over 110 mha was vulnerable to climate change that spread across 26 typical AESR in 11 states in India. Of the 74 mha under agriculture in the region, MODIS dataset indicated $47 \mathrm{mha}$ as agriculturally vulnerable while coarser resolution of AVHRR dataset indicated a conservative estimate of 29 mha. First ever estimates of agricultural vulnerability for India indicates 20.4 to $33.1 \%$ agricultural land under risk from climate change.
\end{abstract}

\section{INTRODUCTION}

Climate change research predominate international dialogue and negotiations in view of growing evidence of change in climate especially during last three decades owing to increased variability and occurrences of extreme climatic event that impact human life. Scientific community opine that anthropogenic causes like increasing GHG emissions is the factor for growing weather aberrations (IPCC, 2007a, b,c; 2008; 2012). Measuring and mapping climate change vulnerability to understand its impact has been accepted as an important initial step to strategize adaptation and mitigation measures (Parry et al., 2007; Turner et al., 2003a, b; Brinkmann, 2006; Carney 1998; UNDP, 2010, USAID, 2013, de Sherbininet al.,2014; Edwards et al., 2007, Fischer et al., 2002). Factors and indicators have been identified for study of local, sub-regional, sub-national and national studies. To understand vulnerability of agriculture in rainfed region in India, a study was carried out to assess change in Land Use - Land Cover (LULC) and on state and vigour of vegetation using Normalized Difference Vegetation Index (NDVI) and GIS tools to identify extent of agricultural vulnerability. To understand role of weather variables, standard precipitation index (SPI) was used to explain variability in vegetation vigour in the arid, semi-arid and subhumid regions of the country. Temperature variation was notanalysed explicitly as length-of-crop-growing- period was studied. Study was limited to understand the genesis and impact of extreme weather events and their resultant impact on LULC, NDVI and LGP. Time - series satellite data and data products help in examining impact of weather aberrations and

Corresponding author. R. Kaushalya.E-mail address: kausalya@crida.in climate change on bio-physical cover of earth like vegetation, land use, water resource and soils (Murthy and SeshaSai 2011). A national program wasinitiated by Indian Council of Agriculture Research (ICAR) to study impact of climate change on Indian agriculture in 2011 and the present study was carried out in Central Research Institute for Dryland Agriculture (CRIDA) to assess agricultural vulnerability in rainfed regions in India using NDVI and mapping the extent of agricultural vulnerability (Kaushalyaetal., 2013; Rama Raoet al.,2013).

It is accepted that the severity of impacts of extreme and nonextreme weather and climate events depend strongly on the level of vulnerability and exposure to these events and are dynamic, varying across temporal and spatial scales and altered by socio-economic, demographic, cultural, institutional and environmental factors. Reduction of vulnerability is a core common element for developing strategy for adaptation and for disaster risk management (IPCC, 2012; Fischer etal., 2002) and also the objective of ICAR research program- National Initiative for Climate Resilient Agriculture (NICRA) under which the present study was conducted. Unlike impact assessment studies that document potential consequences of a climatic phenomena viz., drought or a process like dumping of hazardous waste leading to non-point pollution, vulnerability assessment focuses on factors of human or environment origin that combined or separately drive and cause vulnerability of a community or ecosystem (Vogel and O'Brien, 2004; Schroter etal., 2005; Preston etal., 2011; Fussel, 2009). For the present study, IPCC SREX framework (2012) was followed and determinants of risk viz., hazard, exposure and vulnerability was analysed using NDVI and SPI as indicators for exposure and variations in LGP as an indicator forsensitivity of an ecosystem (USAID, 2013). 
In order to understand variations in climate and its attendant impact on Indian agriculture imparting degrees of vulnerability, a temporal study of NDVI variations was undertaken using Advanced Very High Resolution Radiometer (NOAAAVHRR)(15-day, $8 \mathrm{~km}) \quad$ NDVI dataset (http://www.glcf.umd.edu/data/gimms/) and Moderate Resolution Imaging Spectro-radiometer(MODIS-TERRA)(16day,250m) NDVI data product(http://mrtweb.cr.usgs.gov/). Time-series NDVI datasets were downloaded from their respective websites and a methodology was developed to assess and map agricultural vulnerability in India as there is yet no consensus on what constitutes 'best practice' in spatial vulnerability assessment (PROVIA 2013, Preston et al., 2011, UNDP, 2010; Celiset al., 2007). GIMMS (Global Inventory Modelling and Mapping Studies) dataset of NOAA- AVHRR with $8 \mathrm{~km}$ ground resolution were used to analyse agricultural vulnerability at regional and sub-national levels with state as administrative unit and agro-ecological sub-region (AESR) for a scientific agro-climatic understanding of vulnerability and exposure for the study period 1982-2006. MODIS - TERRA NDVI data product with $250 \mathrm{~m}$ ground resolution was useful to assess vulnerability trends at a lower level i.e., district(administrative unit that implements strategies at local level) for the time period 2001 to 2012. Standard Precipitation Index (SPI) instead of actual rainfall data was used to corroborate extreme weather events with resultant NDVI variations (Mckeeet al.,1993; Saikia and Kumar, 2011; Dadhwal, 2011).

\section{CONCEPTS USED FOR AGRICULTURAL VULNERABILITY ANALYSIS}

The Indian rainfed agriculture conversely called dryland agriculture is carried out in over $80 \mathrm{~m}$ ha out of a net sown area of $142 \mathrm{~m}$ ha in the country. The vast region has climate ranging from arid in western India to semi-arid in north-west India skirting the arid tract and in large parts of southern peninsula to hot dry and hot moist sub-humid climate in parts of southern peninsular region and in central India. Rainfed agriculture based on south-west monsoon occurring during the months of JuneSept, is the main source of water for agriculture which corresponds with the main agricultural season locally called Kharif. Residual moisture is utilized with supplemental irrigation to grow a second crop in post-monsoon period during Oct/ Nov till Feb/March and referred to as Rabi season. Due to this rainfall regime, agricultural fields have seasonal vegetation cover while the forests are essentially deciduous in nature. In view of the close link between rainfall and agriculture in rainfed regions in India, these two aspects were selected to study temporal trend to analyse any pattern in change due to climate variability or climate change over a period of time. As stated earlier, AVHRR NDVI data products are available from 1982 onwards and MODIS TERRA data from 2001. Hence the two data sets were taken for a 30-year study period i.e., 1982-2012. To understand the impact of climatic variability on agriculture, resulting variability in length-of-crop-growing period which directly affects agricultural production in India, was analysed. Thus these three factors - vegetation, rainfall and crop growing period represented by NDVI, SPI and LGP were used as indicators for analysing impact of climate change on rainfed agriculture in India (Kaushalyaet al.,2013; Kaushalyaet al., 2014).

\subsection{Normalized Difference Vegetation Index (NDVI)}

NDVI derived from 2-band information (Red and Near-infra Red) of multi-spectral imagery of a satellite data is a contraststretch ratio calculated from Red and Near-Infrared (NIR) bands of sensors like LANDSAT - TM; AVHRR; IRS-1B, 1C, 1D, P6 satellite based sensors LISS-3 / LISS-4; and MODISTERRA besides several others. NDVI from AVHRR and MODIS data with red reflectance in band 1 and NIR reflectance in band 2 is calculated as follows:(band 2-band 1) / (band $2+$ band 1). NDVI takes advantage of typical low reflectance values of vegetation in red wavelength range which corresponds with chlorophyll absorption and high reflectance values in NIR range which signifies leaf structure, thereby enhancing contrast between vegetated, un-vegetated and sparsely vegetated areas.Study of land use-land cover change (LCCS) helps in identifying NDVI variations in agriculture, plantation, forest and open scrub. Correlating rainfall pattern with NDVI timeseries data can indicate which areas are vulnerable and exposed to climatic variation. Use of NDVI is particularly advantageous in sub-tropical regions as in India, Asia and Africa where dependence on agriculture is high and study of vegetation response to rainfall in the event of scarce climate data, could help in drawing coping strategies and improving adaptation capacity among farmers.

\subsection{Standardized Precipitation Index (SPI)}

Standardized Precipitation Index (SPI) represents total difference in precipitation for a given period of time from its climatic mean and then normalized by standard deviation (SD) of precipitation for the same period. It provides an improved tool to assess variations in precipitation and associated impacts (Mckeeet al.,1993; Saikia and Kumar, 2011). Hence, SPI instead of actual rainfall data was used for present study. India Meteorological Department (IMD) provides daily rainfall data of more than 100 years for numerous stations from archives. Daily girded rainfall data set for 1901-2007, developed by Rajeevanet al. (2008) for 1384 stations was used for the present study. Rainfall data on a regular grid of $1^{0}$ lat. x $1^{0}$ long., were used to calculate SPI. Long-term precipitation record was fitted to a probability distribution which was then transformed into a normal distribution so that mean SPI for a location and desired period was equal to zero. Positive SPI values indicate greater than median precipitation, while negative values indicate less than median precipitation. As SPI is normalized, both wetter and drier climates can be presented in similar manner and both wet and dry periods denoting flood and drought could be monitored using SPI thus making it location and timeindependent. McKee et al., (1993) used SPI values to define drought intensities in USA. Accordingly, SPI of $\leq 1.00$ for any given period was considered as start of reduced rainfall period that could lead to drought, if prolonged and drought is said to occur at any time when SPI was continuously negative and reached -1.0 or less. Drought event was said to end when SPI become positive. Thus, use of SPI insteadof actual rainfall data for the study period was useful to identify drought and flood events and corresponding NDVI.

\subsection{Length-of-Crop-Growing-Period}

NDVI was used to estimate length-of-crop-growing-period.A method was developed to identify Start-of-Season (SOS) and End-of-Season (EOS) using NDVI temporal dataset. To identify crop phenology stage, NDVI Threshold Value (TV) was identified for Kharifand Rabi seasons for each AESR using average NDVI value for three normal rainfall year (when rainfall deviations was $<25 \%$ ). Normal rainfall years varied across India, given the large size of Indian sub-continent. TV of LGP assumes start / onset of cropping season (SOS) when NDVI crosses TV and moves in an upward direction. End of Season (EOS) is identified when NDVI moves below 
designated TV. To find TV, actual NDVI value of 15-day composite for an AESR was plotted and least NDVI value for corresponding season was taken as TV.Variations in LGP as a result of change in SOS or EOS affects agricultural production and yield as rainfed regions lack assured source of irrigation to support crops in case of monsoon failure, delay in its' onset, early withdrawal or intermittent breaks of over 2 weeks which affects crop phenology and in turn, crop growth and yield. Thus, variations in LGP can indicate how sensitive a region and its cropping system is to climate variability, which in turn indicates vulnerability of agricultural production system in a region. Data on variations in LGP can be useful to develop suitable crop variety and package of practices for cultivation in any given region. Crop Contingency Plans are coping strategies drawn to meet situation arising from late onset or early withdrawal of monsoon or long intermittent break in rainfall during the main rainy season.Based on CV of Max NDVI and SPI, variations of LGP during Kharif and Rabi seasons in various AESR in India were analysed.

\subsection{Data products used}

Time-series NDVI data products of AVHRR space-borne sensor of NOAA polar-orbiting satellites are available as 15-day composites with ground resolution of $8-\mathrm{km}$. The first two bands out of the five, i.e., Red $(0.58$ to $0.68 \mu \mathrm{m})$ and Near-Infrared $(0.75$ to $1.1 \mu \mathrm{m})$ are useful for mapping clouds, land surface and delineate surface water bodies respectively when combined. Hence these are also useful for monitoring vegetation (Tucker et al.,2004, 2005). AVHRR NDVI data product is a part of the GIMMS dataset and was obtained from AVHRR instrument on board NOAA satellite series 7, 9, 11, 14, 16 and 17 for the period 1981 till 2006. The data are corrected for calibration, view geometry, volcanic aerosols and other effects not related to vegetation change and are made available for download from Global Land Cover Facility (GLCF) website as 15-day Maximum-Value Composite) (GIMMS, 2004).In addition to this, NASA operated sensor Moderate Resolution Imaging Spectro-radiometer (MODIS) on board TERRA and AQUA earth observation research satellites with sweeping swath of $2330 \mathrm{~km}$ width and covering earth in 1-2 days in 36 discreet spectral bands, supplements earth observation seamlessly with a higher resolution NDVI dataset (http://terra.nasa.gov/). MODIS TERRA data has been found to be ideal for monitoring largescale changes in biosphere and was hence chosen for assessing agricultural vulnerability at a relatively finer-scale i.e., district in India. MODIS (16-day, 250m) NDVI composite products are freely available from Land Processes - Distributed Active Archive Centre (LPDAAC) website of USGS. The Indian subcontinent is covered in 13 scenes and NDVI data is available from February 2000 onwards till date.

\section{METHODOLOGY FOR ASSESSING AGRICULTURAL VULNERABILITY}

Time-series NDVI data products of both AVHRR and MODIS were analysed to identify the spatial extent of agricultural vulnerability in India. AVHRR NDVI data product which is available for whole of Indian sub-continent was sub-set from global coverage as a tile for each year starting from 1982. Bimonthly NDVI images (15-day, $8 \mathrm{~km}$ ) were stacked and preprocessed, followed by identification of pixel-wise Max NDVI for arriving at Maximum Greenness for any pixel during corresponding year for the period 1982- 2006. This was followed by estimation of mean and standard deviation for Max NDVI. To understand variability in Greenness as an indicator of agricultural vulnerability, CV of Max NDVI was estimated which formed the basis for analysing agricultural vulnerability. Due to coarse resolution of dataset, agricultural vulnerability was identified at a regional level (AESR) as indicated earlier. The extent of vulnerable region was identified at national-level. Method for identifying and estimating extent of agricultural vulnerability is indicated in Figure 1.

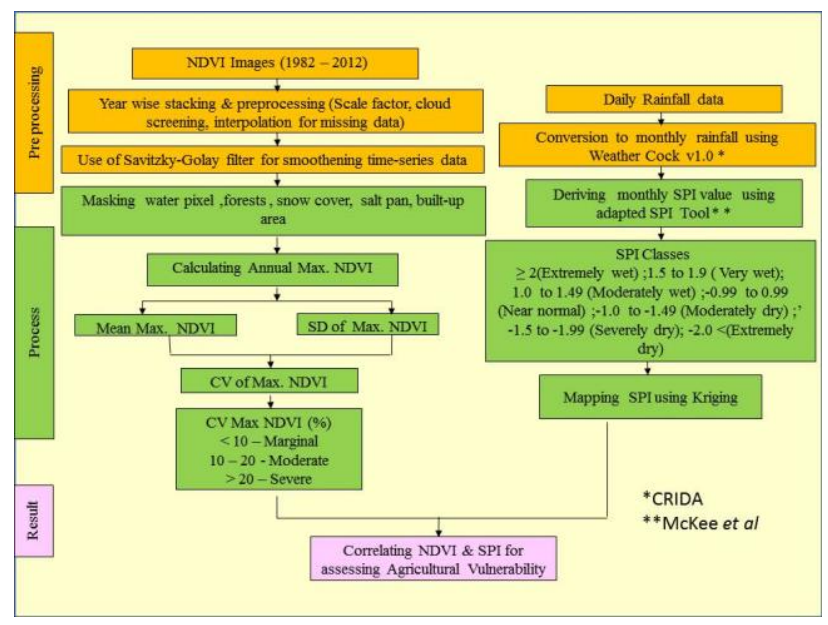

Figure1. Methodology for assessing agricultural vulnerability

Spatial pattern of rainfall (1982 - 2006) was mapped by interpolating $1^{0} \times 1^{0}$ rainfall grid data by Kriging. SPI was calculated from 110-year daily rainfall records for each grid pointand trends were analysed. It was seen that rainfall was highest during July-August and corresponding Max NDVI occurred in Sept-Octoberannually. Analysis of annual and southwest monsoon rainfall pattern was used assuming 1982 as base year. Figure 2 indicates frequency of drought in India based on SPI.

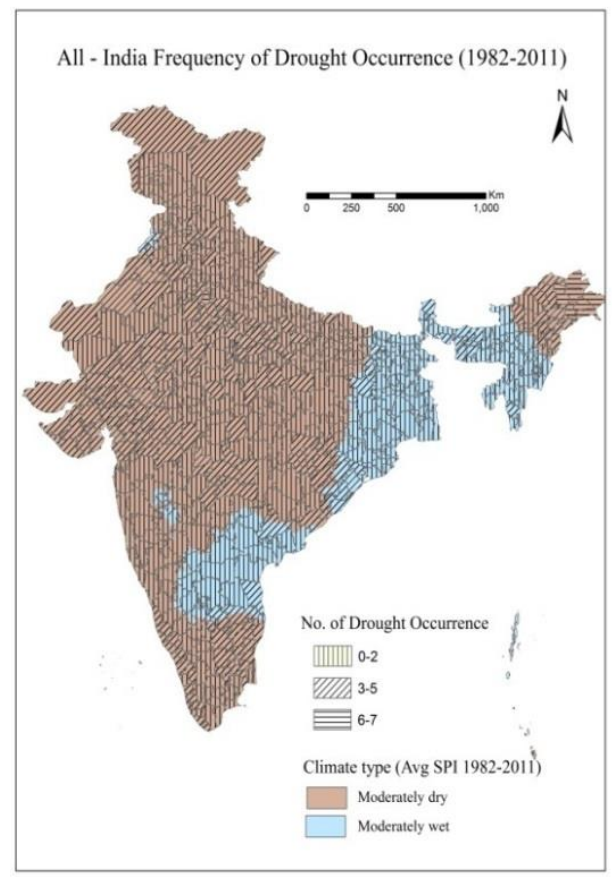

Figure2. Occurrence of drought events in India based on SPI 


\section{ASSESSMENT OF AGRICULTURAL VULNERABILITY USING NDVI DATASETS}

AVHRR bi-monthly NDVI images were sub-set, downloaded and stacked and pre-processed. Pixel-wise Max NDVI was identified to arrive at Maximum Greenness for a given pixel during corresponding year for the study period 1982-2006. This was followed by estimation of mean and standard deviation for Max NDVI. To understand variability in Greenness as an indicator of agricultural vulnerability, coefficient of variation (CV) of Max NDVI was calculated which formed the basis for vulnerability analysis. The output helped in identifying regional agricultural vulnerability. Due to coarse resolution of dataset, agricultural vulnerability was identified at agro-ecological subregions (AESR) level. These regions are vulnerable due to low rainfall, frequent drought due to high rainfall variability and a gradual drying phase. Study indicated that a conservative estimate of 29 mha or $20.4 \%$ of net sown area in India was vulnerable to climate change.

CV of annual Max NDVI was estimated to assess trend in NDVI variability across various states and AESR in the country. In arid regions in western Rajasthan and Gujarat and south-central India in arid districts of Bellary and Anantapur, vegetation cover remainedsparse as agriculture is restricted to short window during southwest monsoon period. However the large livestock population contributes to increased vulnerability as fodder availability could be critical in the event of drought. Study of trend in Max NDVI during 1982-2006 (Figure 3a \& b) indicates a positive trend in vegetation index in this critical zone. In semi-arid and sub-humid zones which account for large area under rained agriculture, the natural resource base supporting agricultural enterprise is poor owing to shallow soil cover and falling groundwater table, in addition to presence of large number of marginal and small farm holdings that depend on southwest monsoon rainfall for carrying out agricultural operations. Agricultural vulnerability in this zone increases owing to impact of climate variability. In the humid regions where agriculture is undertaken in two to three cropping seasons annually, floods and/or drought could be devastating. Figure 3 $\mathrm{a} \& \mathrm{~b}$ indicates a declining trend in AVHRR NDVI in humid western coastal zone and the north-eastern region of India which could be devastating for local and national economy. However, in the recent MODIS dataset, this was not seen, except in a few districts in the aforesaid regions. MODIS bimonthly (16 days) NDVI dataset of $250 \mathrm{~m}$ resolution for 20012012 period was similarly processed and spatial variability of Greenness was identified at a larger scale namely district, which is an administrative unit entrusted with implementation of policy at local-level. Study indicated that over $47 \mathrm{mha}$ or $33 \%$ of net sown area was vulnerable to climate change. MODIS dataset was also used to study variability in length-of-cropgrowing period (LGP) as an indicator of sensitivity of agricultural vulnerability.

\subsection{Study of variations in LGP imparting sensitivity to rainfed agriculture}

As recommended by $\operatorname{IPCC}(2007,2012)$ NDVI was used as an exposure indicator to study variations in LGP, considered a sensitivity indicator. To study variations in LGP that contributes to agricultural vulnerability in a region, a method was developed to identify Start-of-Season (SOS) and End-of-Season (EOS) for each AESR in India as indicated earlier. Data on variations in LGP help in developing appropriate package of practices for crop variety selection and crop management suitable for late onset or early withdrawal of monsoon or long intermittent break in rainfall during rainy season.Based on $\mathrm{CV}$ of Max NDVI and SPI trends, variations of LGP in various AESR across the country was analysed. A methodology was developed to study trends in variations in LGP in both Kharif and Rabi cropping seasons across India.Mann Kendall Test was performed to analyse the trend in LGP derived from AVHRR and MODIS datasets. Out of 57 ASER (excluding J\&K), LGP showedan increasing (positive) trend in 17 AESR regions with $1 \%$ significance while in eight AESR the increase was significant at 5\% level. In 32 AESR, there was no significant trend. However 13 of these 32 AESR regions recorded declining trend in LGP as indicated in Figure 4.

In arid agro-ecological region covering western Rajasthan, Kachchh in western Gujarat and Anantapur in Peninsular India, there was no change in lower limit of LGP which denotes least number of days available for crop growth. However, there was a decline in lower limit of LGP in sub-humid rain-shadow region located in Maharashtra and Karnataka besides NellorePrakasam region in the state of Andhra Pradesh in addition to Madhya Pradesh and Chattisgarh in central India. In arid Jaisalmer district, there was no change in LGP while in semiarid districts of western Rajasthan and arid district of Anantapur, there was an increase in LGP; in rest of India, there was a decrease in LGP that augurs hardship to rainfed farmers in the region. Steep decrease in upper limit of LGP was noticed in prime agricultural areas in the states of Madhya Pradesh, Maharashtra and Telangana that will hurt farming communities in the region.

Analysis of MODIS dataset indicated a larger extent of agriculturally vulnerable region in India owing to finer ground resolution $(250 \mathrm{~m})$ compared to that of AVHRR. Itenabled a precise analysis and accurate estimation of extent of vulnerable regions in India. There was dissimilarity in trends in lower limit of LGP as identified using MODIS and AVHRR datasets. While the former indicated a rise in lower limit of LGP in several AESR in central and southern India and a decrease in others during the period 2001-2012, the latter indicated no significant change in LGP (Kaushalya et al. 2014).
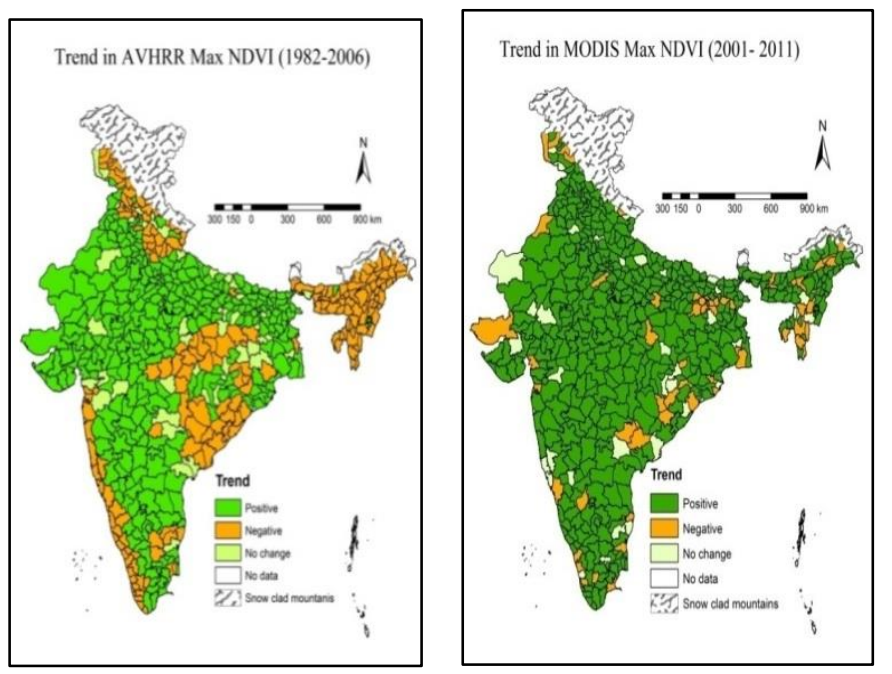

Figure 3 a \& b. Trend in NDVI

\section{MAPPING SPATIAL EXTENT OF AGRICULTURAL VULNERABILITY}

Extent of agriculturally vulnerable regions was mapped based on variations in CV of Max NDVI of datasets obtained from 
NOAA-AVHRR and MODIS-TERRA satellites. The raster image of vulnerable region identified using CV Max of NDVI was overlaid with vector layer of boundary of AESR/ state/ district. Polygons depicting different categories of vulnerability based on CV of Max NDVI were mapped. Based on AVHRR dataset 87 districts encompassing 83.96 mha area was found to be vulnerable. Of these 24 mha was mildly vulnerable (10-20\% CV), 4.0 mha was moderately vulnerable $(20-30 \%)$ and over 0.52 mha was severely vulnerable (>30\%) (Figure 5).Using MODIS dataset, it was seen that over 122 districts were vulnerable and exposed to climate change. The spatial extent of this area was 110 mha of which 39 mhawas found to be mildly vulnerable (CV 10-20\%), 5.6 mha moderately vulnerable (20-30 $\%$ ) and over $1.4 \mathrm{mha}$ severely vulnerable (Figure 6).

\section{TYPOLOGY OF AGRICULTURALLY VULNERABLE AREA IN RAINFED REGIONS IN INDIA}

In view of the trends signified by indicators used for the study, it was essential to develop typologies to understand the hazard and risk of climate change based on vulnerability and exposure of the districts. To understand the type of vulnerability faced by agriculture in these districts, they were classified and grouped based on several parameters which enabled construction of typologies that could form the basis for developing strategies for adaptation and mitigation for agricultural vulnerability. The basis for classifying vulnerable districts in various typologies was as follows:

1. Based on actual area under agriculture in vulnerable district - This would indicate the relative importance of agricultural activity in a given district and would help in determining the priority of adaptation or mitigation strategy.

2. Based on bio-climate- Requirement of agriculture in various bio-climates, viz., arid, semi-arid, sub-humid or humid are markedly different and this typology would help in identifying typical strategies useful for specific requirement of the district.

3. Based on normal LGP estimated based on agrometeorological parameters- Variations in LGP cause agricultural vulnerability. Normal LGP identified using climatic parameterswas used to develop baseline-typology which was then used to study variations in LGP as a result of climate change (Higgins and Kassam, 1981).

4. Based on LGP derived from NDVI estimated from AVHRR and MODIS datasets - Variations in LGP estimated based on these two datasets were compared with normal LGP identified using FAO model as indicated earlier.

5. Based on major cropping systems prevalent - Typologies were drawn based on dominant cropping systems in vulnerable districts. This helped to identify which crops were vulnerable and what could be its impact on the people and local economy. Impact on livestock component of agriculture was also analyzed for assessing fodder availability during lean period.

Study indicated that in arid zone, 6 AESR in 4 states with 29 districts were found to be vulnerable and 12 crop types including cereals- mainly millets and pulses were predominant and LGP ranged from 50 to 120 days (Table-1 Appendix). The LGP derived from AVHRR and MODIS indicated a small but crucial reduction in lower limit and upper limit of LGP compared to long-term LGP estimated using FAO model (1983). Crops that were vulnerable as a result of this were maize, cotton and groundnuts which are recently introduced high-value commercial crops.

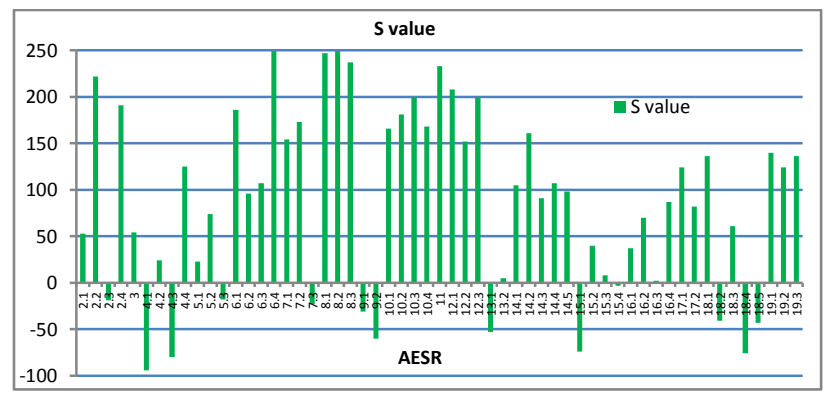

Figure 4. Significance of variability in LGP based on Mann Kendall Test

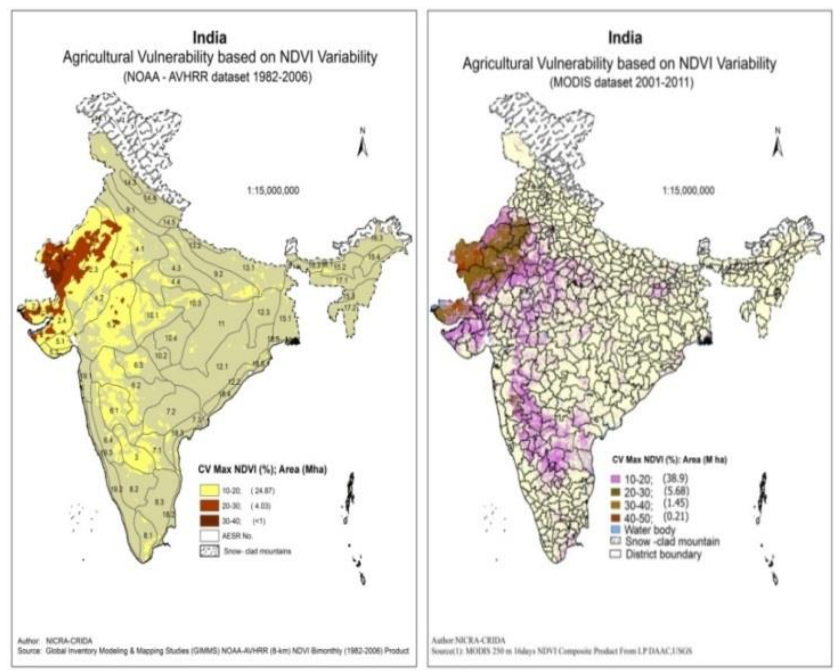

Figure $5 \& 6$. Extent of agricultural vulnerable region at AESR \&district-level

The region is also dominated by animal husbandry of small ruminants which is an important component of local economy. In recent years, cattle and buffaloes were being reared that increased vulnerability. In semi-arid region, 15 AESR in 8 states encompassing 80 districts with 43.79 mha was vulnerable and 16 cereals, pulses, oilseeds and cash crops that were being cultivated could be affected due to reduction in lower and upper limits of LPG from 60 to 90 days and 140-160 days instead of 180 days respectively. This region is dominated by bovine population that could be adversely affected. In dry sub-humid region, 4 AESR covering 5 states and 10 districts encompassing 4.27 mha with an LGP of 150-180 days was vulnerable and crops viz., paddy, maize, soybean, wheat, black gram and green gram besides coriander, sugarcane and cotton could be affected due to reduction in lower limit of LGP to 100-120 days. In moist sub-humid region, 2 AESR of central India highlands covering $0.74 \mathrm{~m}$ ha could be adversely affected.

\section{CONCLUSION}

Satellite-based NDVI obtained from NOAA-AVHRR and MODIS-TERRA (1982-2012) was useful to assess the extent of agricultural vulnerability in India. The indicators used for study - NDVI, SPI and LGP were suitable for a spatial study using 


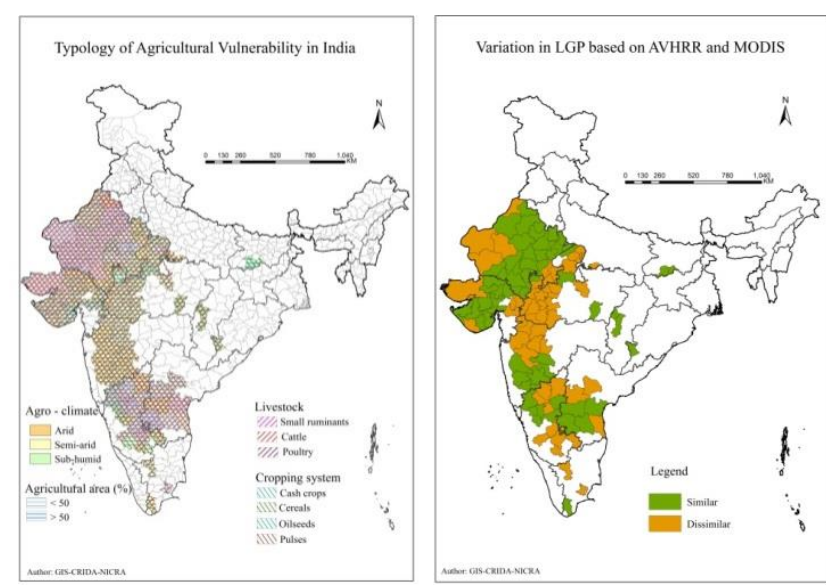

Figure 7. Typology of agricultural vulnerability in India

methodology developed for assessment of agricultural vulnerability. The study helped in estimating extent of agricultural vulnerability for the first time in India. Identification of vulnerable districts in over $110 \mathrm{mha}$ in 26 AESR in 11 states in the country will facilitate drawing of strategies for risk management, crop contingency plan and optimum use of available resources. There was a difference in extent of vulnerable region identified using AVHRR and MODIS datasets essentially due to variation in resolution. Quantitative analysis of relationship between AVHRR data set (mean and Max NDVI) with actual rainfall occurrence in whole of India in two typical years, i.e., 1982 \& 2006 revealed that SD of NDVI was less than that of rainfall. Between 1982 and 2006, there was only $5 \%$ variation in All-India rainfall, $10 \%$ in mean NDVI and 5\% in Max NDVI with no discernable trend at national-scale. Overlapping datasets of 2001-2006 period revealed that Max NDVI was similar spatially and temporally. There was dissimilarity in trend in NDVI in only 74 districts and data inconsistency in seven districts. Variations in Annual Maximum NDVI estimated during 1982-2006 indicated a large variation in vegetation dynamics in the country owing to climatic variability although the trend in last decade as depicted in MODIS dataset was contrary. It may be concluded that study of temporal NDVI data products was useful to assess slow change in agricultural land use and in identifying vulnerable regions therein.

\section{ACKNOWLEDGEMENTS}

The authors thanks ICAR, NICRA ,CRIDA, GLCF , LPDAAC for funds and data respectively.

\section{REFERENCES}

Birkmann, J., 2006. Measuring vulnerability to natural hazards: Towards disaster resilient societies. TERI, UNU, ISBN 817993-1226, 1-524.

Carney, D., 1998. Sustainable rural livelihoods: What contribution can we make? In: Carney, D. (Eds.), Department for international development's natural resources advisers conference. London: DFID.

Celis, D., Pauw, E. D., Geerken, R., 2007. Assessment of Land Cover and Land Use in Central and West Asia and North Africa - Part 1: LULC - Base Year 1993. ICARDA.
Dadhwal, V.K., 2011. Retrieval of biophysical parameters from satellite data. (In): Rao, V.U.M., Rao, A.V.M.S., Kumar, P.V., Desai, S., Saikia, U.S., Srivastava, N.N. and B. Venkateswarlu (Eds.), Agricultural drought: Climate change and rainfed agriculture. Lectures notes of the $5^{\text {th }}$ SERC school, CRIDA 5258.

deSherbinin, A., Chai-Onn, T., Giannini, A., Jaiteh, M., Levy, M., Mara, V., Pistolesi, L., 2014. Mali climate vulnerability mapping. Technical report for the USAID African and latin American resilience to climate change (ARCC) project. Washington, DC: USAID.

Edwards, J., Gustafsson, M., Naslund-Landenmark, B., 2007.Handbook for vulnerability mapping, EU and International affairs department of the Swedish rescue services agency.http://www.nsc.org.in/ANNEXES/3.2.4\%20Risk\%20as sessments\%20and\%20vulnerability\%20maps/Handbook\%20for \%20vulnerbaility\%20mapping.pdf

Fischer, G., Shah, M., Van Velthuizen, H., 2002. Climate change and agricultural vulnerability: A special report prepared by the international institute for applied systems analysis under United Nations institutional contract agreement no. 1113 Climate Change and Agricultural Vulnerability as a contribution to the World Summit on Sustainable Development. 1-152 http://www.accc.gv.at/pdf/JB-Report.pdf.

Fussel, H.M., 2009. Review and quantitative analysis of indices of climate change exposure, adaptive capacity, sensitivity and impacts. Background note to the World development report 2010.1-34.

GIMMS, 2004. Global Inventory Modelling and Mapping Studies http://www.glcf.umd.edu

Higgins, G.M., Kassam, A.H., 1981. The FAO Agro-ecological zone approach to determination of land potential.Pedologie 31(2): 147-168.

IPCC, 2007. Climate Change 2007: Impacts, Adaptation and Vulnerability. Contribution of Working Group II to the Fourth Assessment Report of the Intergovernmental Panel on Climate Change, M.L. Parry, O.F. Canziani, J.P. Palutikof, P.J. van der Linden and C.E. Hanson, Eds., 976pp.

IPCC, 2007a. Climate Change 2007: Synthesis Report. Contribution of Working Groups I, II and III to the Fourth Assessment Report of the Intergovernmental Panel on Climate Change [Core Writing Team, R.K. Pachauri, and A. Reisinger (eds.)]. IPCC, Geneva, Switzerland, 104 pp.

IPCC, 2007b.Impacts, Adaptation and Vulnerability. Contribution of Working Group II to the Fourth Assessment Report of the Intergovernmental Panel on Climate Change [Parry, M.L., O.F. Canziani, J.P. Palutikof, P.J. van der Linden, and C.E. Hanson (eds.)]. Cambridge University Press, Cambridge, UK and New York, NY.

IPCC, 2007c. Appendix I: Glossary. In: Climate Change 2007: Impacts, Adaptation and Vulnerability. Contribution of Working Group II to the Fourth Assessment Report of the Intergovernmental Panel on Climate Change [Parry, M.L., O.F. Canziani, J.P. Palutikof, P.J. van der Linden, and C.E. Hanson (eds.)]. Cambridge University Press, Cambridge, UK, and New York, NY, pp. 869-883. 
IPCC, 2008.Climate Change 2007 - Synthesis report.WMO \& UNEP.

IPCC, 2012.Managing the Risks of Extreme Events and Disasters to Advance Climate Change Adaptation. A Special Report of Working Groups I and II of the Intergovernmental Panel on Climate Change [Field, C.B., V. Barros, T.F. Stocker, D. Qin, D.J. Dokken, K.L. Ebi, M.D. Mastrandrea, K.J. Mach, G.-K. Plattner, S.K. Allen, M. Tignor, and P.M. Midgley (eds.)]. Cambridge University Press, Cambridge, UK, and New York, NY, USA, 582 pp.

KaushalyaRamachandran, Venkateshwarlu, B., Ramarao, C. A., Rao, V. U. M., Raju, B. M. K., Rao, A.V. M. S., Saikia, U. S., Thilagavathi, N., Gayatri, M., Satish, J., 2013. Assessment of Vulnerability of Indian Agriculture to rainfall variability - Use of NOAA-AVHRR $(8 \mathrm{~km})$ \& MODIS (250m) Time-Series NDVI Product. Climate Change \& Environmental Sustainability, 1(1):37-52.

KaushalyaRamachandran, Gayatri, M., Praveen, V., Satish, J., 2014.Use of NDVI variations to analyse the length of growing period in Andhra Pradesh.Journal of Agrometeorology. 16(1): $112-115$.

McKee, T. B., Doesken, N. J., Kleist, J., 1993. The relationship of drought frequency and duration to time scales. $8^{\text {th }}$ Conf.On Applied Climatology, 17-22 January, Anaheim, CA, pp.179184.

Murthy C.S., SeshaSai, M.V.R., 2011. Agricultural drought monitoring and Assessment. (In): Roy, P.S., Dwivedi, R.S. and Vijayan, D. (Eds.), Remote Sensing Applications. NRSC/ISRO, 303-330, www.nrsc.gov.in

Parry, M.L., Canziani, O.F. Palutikof, J.P. van der Linden, P.J., Hanson, C.E., 2007. Climate Change 2007: Impacts, Adaptation and Vulnerability. Contribution of Working Group II to the Fourth Assessment Report of the Intergovernmental Panel on Climate Change, M.L.Parry, O.F. Canziani, J.P. Palutikof, P.J. van der Linden and C.E. Hanson, Eds., 23-78.

Preston, B.L., Yuen, E.J., Westaway, R. M., 2011. Putting vulnerability to climate change on the map: a review of approaches, benefits and risks.Sustainability Science 6(2): 177202.

PROVIA, 2013. Research priorities on vulnerability, impacts and adaptation to climate change consultation document. UNEP.1-43.

Rajeevan, M., Jyoti, B., Jaswal, A. K., 2008. Analysis of variability and trends of extreme rainfall events over India using 104 years of girded daily rainfall data, Geophysical Research Letters (35) LI8707 DOI: 10.1029/2008GL035143.

Rama Rao, C.A., Raju, B.M.K., SubbaRao, A.V.M., Rao, K.V., Rao, V.U.M., KaushalyaRamachandran, Venkateswarlu, B., Sikka, A.K., 2013. Atlas on Vulnerability of Indian Agriculture to Climate Change.Central Research Institute for Dryland Agriculture, Hyderabad, 116p.

Saikia, U. S., Manoranjan Kumar, 2011. Standardized Precipitation Index (SPI): An effective drought monitoring tool. $5^{\text {th }}$ SERC School on Agricultural Drought: Climate Change and Rainfed Agriculture, pp.1-10.
Schröter, D., Acosta-Michlik, L., Arnell, A.W., Araújo, M.B., Badeck, F., Bakker, M., Bondeau, A., Bugmann, H., Carter, T., de la Vega-Leinert, A.C., Erhard, M., Espiñeira, G.Z., Ewert, F., Fritsch, U., Friedlingstein, P., Glendining, M., Gracia, C.A., Hickler, T., House, J., Hulme, M., Kankaanpää, S., Klein, R.J.T., Krukenberg, B., Lavorel, S., Leemans, R., Lindner, M., Liski, J., Metzger, M.J., Meyer, J., Mitchell, T., Mohren, F., Morales, P., Moreno, J.M., Reginster, I., Reidsma, P., Rounsevell, M., Pla, E., Pluimers, J., Prentice, I.C., Pussinen, A., Sánchez, A., Sabaté, S., Sitch, S., Smith, B., Smith, J., Smith, P., Sykes, M.T., Thonicke, K., Thuiller, W., Tuck, G., van der Werf, G., Vayreda, J., Wattenbach, M., Wilson, D.W., Woodward, F.I., Zaehle, S., Zierl, B., Zudin, S., Cramer, W., 2004. ATEAM final report 2004.Potsdam institute for climate impact research. Section 5 and 6 (2001-2004). 1-122.

Tucker, C. J., Pinzon, J. E., Brown, M. E., 2004. Global Inventory Modelling and Mapping Studies, Global Land Cover Facility, University of Maryland, College Park, Maryland, 1982-2006.

Tucker, C. J., Pinzon, J. E., Brown, M. E., Slayback, D., Pak, E. W., Mahoney, R., Vermote, E., Saleous, N. El., 2005. An extended AVHRR 8-km NDVI Data set Compatible with MODIS and SPOT vegetation NDVI Data. Int. J. of Remote Sensing, 26(20): 4485-4498.

Turner II, B.L., Kasperson, R.E., Maston, P.A., McCarthy, J.J., Corell, R. W., Christensen, L., Eckley, N., Kasperson, J.X., Luers, A., Martello, M.L., Polsky, C., Pulsipher, A., Schiller, A., 2003a. A framework for vulnerability analysis in sustainability science.PNAS 100(14): 8074-8079.

Turner II, B.L., Maston, P.A., McCarthy, J.J., Corell, R. W., Christensen, L., Eckley, N., Hovelsrud-Broda, G.K., Kasperson, J.X., Kasperson, R.E.,Luers, A., Martello, M.L., Mathiesen, S., Naylor, R., Polsky, C., Pulsipher, A., Schiller, A., Selin, H., Tyler, N., 2003b. Illustrating the coupled humanenvironment system for vulnerability analysis: three case studies.PNAS 100(14):8080-8085.

UNDP, 2010.Mapping climate change vulnerability and impact scenarios: A guidebook for sub-national planners.1-83.

USAID, 2013. Uganda climate change vulnerability assessment report African and Latin American resilience to climate change (ARCC) report.

Vogel, C., O’Brien, K., 2004. Vulnerability and global environmental change: Rhetoric and reality. AVISO 13, Global environmental change and human security project, Ottawa, Canada. 


\section{APPENDIX}

Table 1: Typology of agricultural vulnerability based on various aspects of rainfed agriculture

\begin{tabular}{|c|c|c|c|c|c|c|c|c|}
\hline \multirow[t]{2}{*}{ Climate } & \multirow{2}{*}{$\begin{array}{l}\text { Physiographic } \\
\text { region }\end{array}$} & \multirow{2}{*}{$\begin{array}{l}\text { Vulnerable State/Districts } \\
\text { (based on MODIS } \\
\text { dataset) }\end{array}$} & \multirow{2}{*}{$\begin{array}{l}\text { Agri. } \\
\text { area (m } \\
\text { ha) } \\
\text { (Bhuvan } \\
\text { NRSC } \\
2005-06)\end{array}$} & \multirow{2}{*}{$\begin{array}{l}\text { Cropping systems } \\
\text { (area '000ha) (CRIDA) }\end{array}$} & \multicolumn{3}{|l|}{ Bio-climate } & \multirow{2}{*}{$\begin{array}{l}\begin{array}{l}\text { Livestock } \\
\text { component }\end{array} \\
\text { (Census } \\
\text { 2007) }\end{array}$} \\
\hline & & & & & $\begin{array}{l}\text { Normal } \\
\text { LGP } \\
\text { (NBSS\&L } \\
\text { UP, 1999) }\end{array}$ & $\begin{array}{l}\text { LGP } \\
\text { derived } \\
\text { from } \\
\text { AVHRR } \\
\text { NDVI }\end{array}$ & $\begin{array}{l}\text { LGP } \\
\text { derived } \\
\text { from } \\
\text { MODIS } \\
\text { NDVI }\end{array}$ & \\
\hline Arid & $\begin{array}{l}\text { Western Rajasthan, } \\
\text { Kachchh, } \\
\text { Kathiawar, } \\
\text { Punjab Plain \& } \\
\text { Deccan Plateau }\end{array}$ & $\begin{array}{l}\text { Western Rajasthan(16); } \\
\text { Western Gujarat (9); } \\
\text { Southwest Karnataka (4); } \\
\text { Andhra Pradesh } \\
\text { (Anantapur) }\end{array}$ & 25.9577 & $\begin{array}{l}\text { Pearl millet, } \\
\text { Groundnut, Cluster } \\
\text { bean, Cotton, Paddy, } \\
\text { Sorghum, Mustard, } \\
\text { Maize, Finger millet, } \\
\text { Sunflower, Green } \\
\text { gram, Castor }\end{array}$ & $60-150$ & $40-120$ & $50-150$ & $\begin{array}{l}\text { Small } \\
\text { ruminants, } \\
\text { Buffaloes, } \\
\text { Cattle, } \\
\text { Poultry }\end{array}$ \\
\hline Semi-Arid & $\begin{array}{l}\text { Gujarat Plain, } \\
\text { Rajasthan } \\
\text { Upland,Gangetic } \\
\text { Plains, Central } \\
\text { Highlands, } \\
\text { Kathiawar } \\
\text { Peninsula, Deccan } \\
\text { Plateau including } \\
\text { Rayalseema\& } \\
\text { Eastern Ghats, } \\
\text { Tamil Nadu } \\
\text { Uplands coastal } \\
\text { Region }\end{array}$ & $\begin{array}{l}\text { Central Gujarat (9), } \\
\text { South-central Karnataka } \\
(10), \text { Western Madhya } \\
\text { Pradesh (20) North \& } \\
\text { eastern Rajasthan (16), } \\
\text { Western Tamil Nadu (3), } \\
\text { Southern Uttar Pradesh } \\
\text { (3), Rayalseema region in } \\
\text { AndhraPradesh(4), } \\
\text { Southern Telangana (2), } \\
\text { Central Maharashtra (10) }\end{array}$ & 43.7879 & $\begin{array}{l}\text { Pearl millet, Finger } \\
\text { millet, Sorghum, } \\
\text { Maize, Paddy, Wheat, } \\
\text { Cotton, Sugarcane, } \\
\text { Mustard, Groundnut, } \\
\text { Sunflower, Cluster } \\
\text { bean, Pigeon pea, } \\
\text { Bengal gram, Soybean, }\end{array}$ & $90-180$ & $60-140$ & $80-160$ & $\begin{array}{l}\text { Cattle, } \\
\text { Buffaloes, } \\
\text { Small } \\
\text { ruminants } \\
\& \text { Poultry }\end{array}$ \\
\hline $\begin{array}{l}\text { Dry Sub- } \\
\text { Humid }\end{array}$ & $\begin{array}{l}\text { Eastern UP \& Bihar } \\
\text { Plain, Narmada } \\
\text { valley, Central } \\
\text { Highlands, } \\
\text { Chattisgarh- } \\
\text { Mahanadi Basin }\end{array}$ & $\begin{array}{l}\text { Central Karnataka (4), } \\
\text { Madhya Pradesh (Guna), } \\
\text { Odisha(Nabarangpur), } \\
\text { Southern Bihar (Gaya, } \\
\text { Jehanabad,Nawada), } \\
\text { Chattishgarh (Durg) }\end{array}$ & 4.26851 & $\begin{array}{l}\text { Paddy, Maize, } \\
\text { Wheat, Soya bean, } \\
\text { Bengal Gram, } \\
\text { Coriander, Green } \\
\text { gram, Cotton, } \\
\text { Sugarcane }\end{array}$ & $150-180$ & $100-160$ & $120-180$ & $\begin{array}{l}\text { Cattle, } \\
\text { Poultry, } \\
\text { Small } \\
\text { Ruminants } \\
\& \\
\text { Buffaloes }\end{array}$ \\
\hline $\begin{array}{l}\text { Moist sub- } \\
\text { Humid }\end{array}$ & $\begin{array}{l}\text { Central highlands in } \\
\text { Madhya Pradesh }\end{array}$ & $\begin{array}{l}\text { Madhya Pradesh (Seoni), } \\
\text { Chhattisgarh } \\
\text { (Kabirdham) }\end{array}$ & 0.74782 & Paddy \&Maize & $150-210$ & $120-180$ & $120-180$ & $\begin{array}{l}\text { Cattle \& } \\
\text { Poultry }\end{array}$ \\
\hline Total & & $11 / 122$ & 74.762 & & & & & \\
\hline
\end{tabular}

